\title{
From coal to wood thermoelectric energy production: a review and discussion of potential socio-economic impacts with implications for Northwestern Ontario, Canada
}

\author{
Jason Ernest Elvin Dampier ${ }^{1 *}$, Chander Shahi ${ }^{1}$, Raynald Harvey Lemelin ${ }^{2}$ and Nancy Luckai ${ }^{1}$
}

\begin{abstract}
The province of Ontario in Canada is the first North American jurisdiction with legislation in place to eliminate coalfired thermoelectric production by the end of 2014. Ontario Power Generation (OPG) operates coal-fired stations in Ontario, with Atikokan Generating Station being the only facility slated to switch to $100 \%$ woody biomass. It is anticipated that this coal phase out policy will have socio-economic impacts. Because of these anticipated changes, in this paper, we review the current state of peer-reviewed literature relating to three burning scenarios (biomass, coal and co-firing) in order to explore the knowledge gaps with regard to socio-economic impacts and identify research needs which should elucidate the anticipated changes on a community level. We reviewed over 150 sources, which included peer-reviewed articles and non-peer-reviewed grey literature such as government documents, non-governmental organization reports and news publications. We found very few peer-reviewed articles related to Canadian studies (even fewer for Ontario) which look at woody biomass burning for thermoelectric production. We identify a number of socio-economic impact assessment tools readily available and present potential criteria required in selecting an appropriate tool for the Ontario context. For any tool to provide meaningful results, we propose that appropriate and robust local data must be collected and analyzed.
\end{abstract}

Keywords: Atikokan, Bioenergy, Boreal, Electricity generation, Energy security, Lignite coal, Social impacts, Wood pellets, Gross regional product

\section{Review}

The province of Ontario in Canada has demonstrated its will to expand renewable energy production, encourage energy conservation and create 'green' jobs with the passing of the Green Energy Act of 2009 [1,2]. These changes have been recognized by one of Canada's most visible environmental non-governmental organizations (ENGO), the David Suzuki Foundation, that Ontario's green energy policies are the most far reaching in North America in terms of clean energy, innovation and jobs [3]. The province is also the first jurisdiction in North America with legislation in place to eliminate coal-fired thermoelectric production, making coal use illegal by the

\footnotetext{
* Correspondence: jedampie@lakeheadu.ca

'Lakehead University, Faculty of Natural Resources Management, 955 Oliver Road, Thunder Bay, Ontario P7B 5E1, Canada

Full list of author information is available at the end of the article
}

end of 2014 [4-6]. In order to be in compliance, the facilities are required to follow all established certificates of approval for air, water and land emissions issued by the Ontario Ministry of the Environment (MOE). Although non-compliance would be highly unlikely after the legislation goes into effect, penalties could be established by the MOE, should a generating station burn coal after 2014.

It is anticipated that these coal phase out policy changes will have socio-economic impacts in all regions where Ontario Power Generation (OPG) operates coal-fired stations, with Atikokan Generating Station (AGS) being the only facility slated to switch to $100 \%$ woody biomass [7], while other coal-burning stations such as Lambton and Nanticoke are slated for decommissioning before the 2014 deadline. In this paper, we define socio-economic impacts in general terms as social and economic well-being of 
community members, with well-being defined, 'as a person's quality of life. This is influenced by a range of factors, including work, family, community, health, personal values, personal freedom and a person's financial situation [8]'. Positive socio-economic impacts provided by a company's involvement in a community can include creating jobs, inducing jobs in other sectors, providing physical infrastructure such as parks and recreation centres, paying municipal taxes and providing charitable donations to civic and community groups. Woody biomass in this paper refers to wood pellets produced from sawdust and forest harvest residues of commercial spruce, pine and fir species. Woody biomass is also obtained from harvesting other underutilized species like white birch (Betula papyrifera Marsh.) and poplar (Populus spp.). Depending on site conditions and tree species, Canadian boreal forest practices typically follow a 60- to 100-year harvesting cycle. The AGS will require a total of 90,000 oven-dried tonnes of biomass wood pellets per year for full conversion [9-12]. This value should be easily achievable. Alam and others demonstrated that there is adequate forest harvest residue and underutilized wood biomass feedstock available in Northwestern Ontario to meet the demand [13]. Furthermore, woody biomass stock would also likely come from sawmill residues and waste, further reducing the pressure on forest resources.

Although Ontario is fully converting to non-coal options, many jurisdictions employ co-firing (burning coal along with woody biomass), which is often seen as more environmentally desirable than burning $100 \%$ coal, since a portion of the greenhouse gas (GHG) emissions will be from fossil fuels and a portion from renewable energy [14]. Co-firing is becoming more common and is being practised at a commercial scale in many countries such as the USA, Finland, Denmark, Germany and Belgium [15]. The ratio of coal to woody biomass is very site specific, and it depends on a number of factors such as furnace and boiler design, physical and chemical fuel characteristics, fuel handling and milling units [15]. Utilizing a life cycle approach at AGS, Zhang and others [16] indicated that co-firing woody biomass (as an alternative to $100 \%$ coal) can be an economically feasible option to reduce GHG emissions in the Ontario context.

At present (2011 values), nuclear power generating stations ${ }^{\mathrm{a}}$ meet $56.9 \%$ of demand and are running at full load throughout a full 24-h period in order to meet energy base load demand. [17]. Base load is considered the minimum level of power demand. Nuclear power ideally meets this base load demand since it has a high electrical production capacity and relatively low production cost. However, nuclear power has less capacity to adjust to fluctuations in demand. Hydroelectric power generation meets $22.2 \%$ of demand and responds to variations in load to meet the peak demand. Peak production stations are employed to make up capacity at maximum demand periods and in emergency situations [17]. These can transition from idle to full power production in short periods to meet these temporary and sometimes unpredictable demands. Peak demand is variable over the course of daily and yearly cycles and is in part contingent on weather conditions and is managed to a degree with time-of-use pricing.

As an important renewable energy source, hydroelectric plants provide 'flexibility in base loading, peaking and energy storage applications' [18]. Many smaller hydroelectric generating stations reduce production overnight, storing water to meet peak demand during the following day, with only the largest hydroelectric stations running throughout the night. If the demand exceeds supply by smaller hydroelectric stations, the natural gas generating stations, which meet $14.7 \%$ of demand, begin production. Under this regime, coal, which only meets $2.7 \%$ of demand, is used as a last resort for voltage support ${ }^{\mathrm{b}}$. The use of coal for power generation has been on a steady decline (Figure 1). Recent additions to Ontario's power mix include wind, which meets $2.6 \%$ of demand, with all other energy sources (including solar power) meeting $0.8 \%$ of Ontario's power demand $[4,19,20]$.

Regardless of the electrical energy fuel source, each option has its own environmental consequences such as release of GHGs, particulates, nitrous oxides and/or sulphur dioxide [22,23]. As public support for coal and other fossil fuels continues to wane, renewable sources are being sought [24-28] with biomass-fired power becoming a viable renewable energy option partially because this technology is 'rapidly deployable, low-risk, regionally indigenous, and inherently grid-compatible [29]'. Wind and solar energy do not possess these characteristics since they depend on weather conditions [17]. Furthermore, woody biomass can provide (1) reserve capacity during peak demand, (2) capacity during routine maintenance at other generating stations and (3) resilience in the power grid, should other generating stations go offline in an emergency.

Whenever the use of woody biomass for power generation is introduced, a variety of public opinions may arise. On the one hand, woody biomass for power generation has many of the above-mentioned benefits; on the other, there is documented public opposition [30,31]. The Greenpeace report, 'Fueling a Biomess', is critical of Canadian provinces' efforts to stimulate biomass fuel for electricity production [32]. The report critiques are directed to the government's 'biomass extraction policies and subsidies [32], and it outlines a number of recommendations to government, many of which represent socio-economic impacts. These include (1) suspend the approval of new bioenergy proposals and conduct a review of existing projects, their wood allocations and 


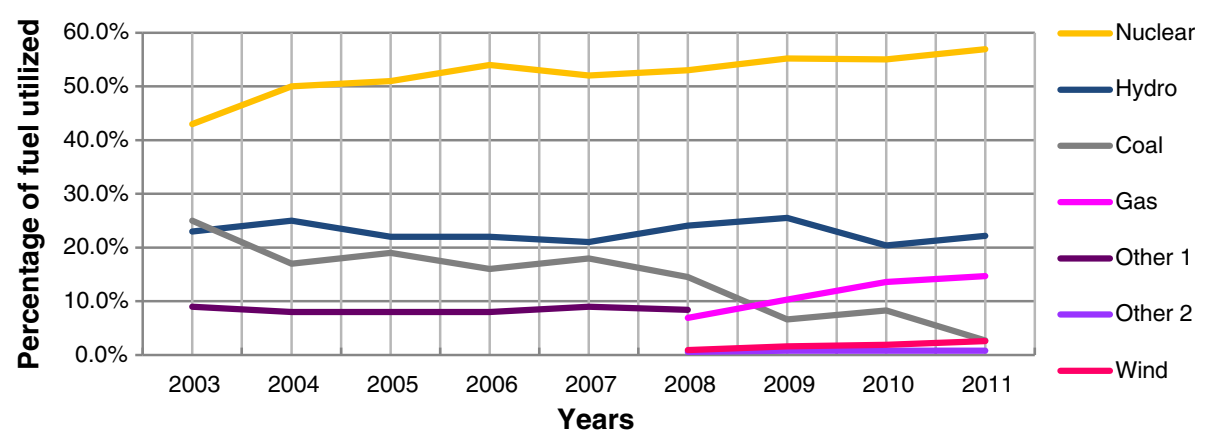

Figure 1 Historical changes in fuel supply used for electricity production from 2003 to 2011. Raw data from Ontario's Independent Electricity System Operator News Releases from 2004 to 2012 [21] were used to establish a 9-year tread (2003 to 2011) for Ontario's electricity power mix in order to provide an Ontario context. Nuclear (yellow line) and hydro (blue line) production levels have remained relatively constant over the period. Electricity produced from coal (grey line) has been steadily decreasing over the time period. In 2008, IESO ceased to report natural gas, oil, wind and alternative fuel sources together (Other 1, dark purple line) and broke it apart to report gas (pink line), wind (magenta) and Other 2 (light purple) separately.

their impacts on communities, climate and forests, (2) preclude low-efficiency electricity-only production from forest biomass and require that waste heat of biomass electric plants be utilized locally and (3) support the production of higher value wood products from public forests to optimize job creation, minimize resource extraction and develop sustainable solutions for forestbased communities [32].

Recommendations such as these imply that the forest management planning process does not routinely incorporate socio-economic considerations. In contrast, forest practitioners, with the responsibility for managing public forests in Ontario, operate under the Crown Forest Sustainability Act (1994) [33] that includes requirements for public consultation and recognizes the necessity for both economic and ecological sustainability. This legislation is implemented through a series of management guides [34] developed to ensure the protection of multiple forest values including cultural heritage [35], resource-based tourism [36], biodiversity [37], natural disturbance pattern emulation [38] and species of interest (e.g. marten [39], woodland caribou [40]). Guide revision is ongoing, science-based, overseen by a joint committee (which includes government, industry, First Nations, academia) and subject to review every 5 years [41]. Despite the processes in place, challenges such as those raised by Greenpeace need to be addressed through standard research protocols.

Therefore, the objectives of this paper are (1) to determine the current state of peer-reviewed literature relating to coal, biomass and co-fire burning in Ontario and to relate the current state of knowledge nationally and globally, looking outside of Ontario when necessary for insights into the Ontario context and (2) to explore the knowledge gaps with regard to socioeconomic impacts, under three scenarios which include 100\% biomass burning, 100\% coal burning and co-firing.

\section{Methods}

In order to determine generally the current state of peerreviewed literature relating to biomass burning for thermoelectric generation in Ontario and to identify knowledge gaps in the peer-reviewed literature, the Thomson Reuters (ISI) Web of Knowledge ${ }^{\mathrm{c}}$ [42] was used to find articles covering the utilization of wood-based biomass in thermoelectric power generating stations. This preliminary search was carried out by following the Boolean search string: 'biomass', 'wood"' and 'thermoelectric"'. Asterisks were used as they provide the function of a 'wildcard' thus increasing the likelihood of words with suffixes being included in the search. We also preliminarily searched simply 'Atikokan' in order to help us establish a baseline of all studies conducted in the Atikokan region.

Secondly, since Ontario policy dictates that alternatives to coal must be implemented, we also conducted a more in-depth literature search related to three common burning scenarios:

- $100 \%$ coal: this was searched since coal is the fuel source that is being phased out at AGS. Although it is not widely used in Canada, it is globally the second most important fuel after oil accounting for $27 \%$ of world primary energy demand [4],

- $100 \%$ biomass: this was searched since biomass is being phased in at AGS. Furthermore, biomass is experiencing more attention globally, for example, increases in demand in Europe as they seek to power industry and reduce GHG emissions concurrently [43] and

- Co-firing coal with biomass: this was searched since co-firing has been an experimental intermediate 
stage at AGS and is employed in many jurisdictions as a shorter term low-cost option to reduce GHG emissions [44].

In this second search, we used the following Boolean topic search in Thomson Reuters (ISI) Web of Knowledge: ('biomass,' 'wood"', 'coal' or 'co-fire') and ('employ"', 'product"' or 'community"') and ('electric"'). We used the search term 'electric"' rather than 'thermoelectric"' as we did in the preliminary search in order to broaden our results. Then, this search was narrowed down separately two more times, the first one by only adding the term 'Canada' to the original topic search and the second one by only adding the term 'Ontario' to the original search. Results where then presented in a pie graph.

Following this, we identified and used relevant articles indicated through forward and backward citations in Thomson Reuters (ISI) Web of Knowledge and Google Scholar $^{\mathrm{d}}$ [45]. Google Scholar was used in order to reduce the likelihood that related sources would be missed. Additionally, we also investigated the non-peer-reviewed literature such as grey literature and news publications as oftentimes useful information relevant to studies such as ours can be found in these source types.

From the retrieved sources utilizing the various abovementioned methods, only those relevant to this paper were included and used to establish a relative abundance of articles categorized by Literature Type, Location, Impacts, Fuel and Combinations. Then, based on the current state of knowledge and gaps, we discuss potential methods for future work, which should elucidate the anticipated policy changes on a community level.

\section{Results and discussion}

Our findings from the preliminary Thomson Reuters (ISI) Web of Knowledge search indicate that very few Canadian peer-reviewed articles investigate biomass burning in thermoelectric generating stations. For example, the search ('biomass' and 'wood"' and 'thermoelectric"') yielded six articles of which only one [46] has any direct bearing to this review. The search 'Atikokan' retrieved 45 articles, with only 8 of these articles having any bearing on this review further indicating that limited work has been conducted to date which is Atikokanspecific [7,46-51].

The secondary search ('biomass' or 'wood"' or 'coal' or 'co-fire') and ('employ"'or, 'product"' or 'community"') and ('electric"') was followed by the narrowing term (and 'Canada'), and again, the narrowing term (and 'Ontario') indicated that out of the 4,954 articles retrieved, only 93 addressed Canada and only 10 addressed Ontario (Figure 2), of which many from Canada or Ontario were actually not suitable sources for this study. Since the literature indicates that most research has been

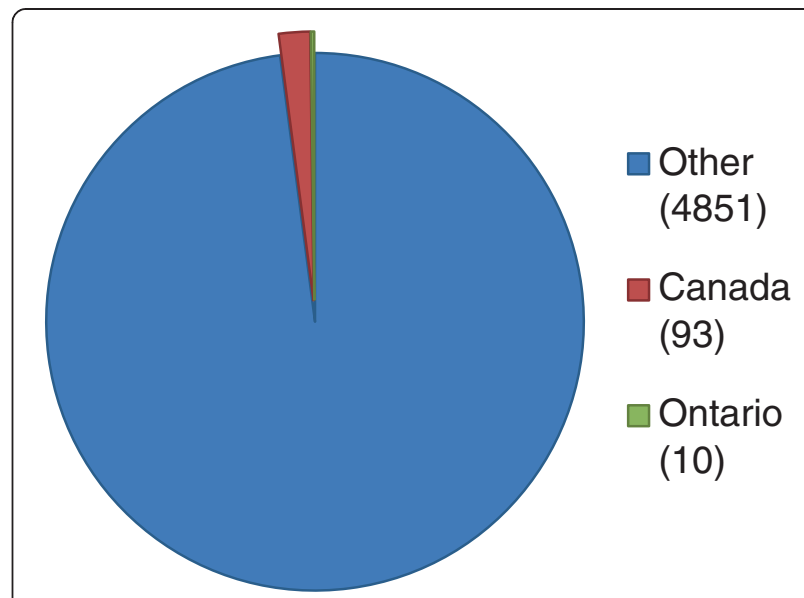

Figure 2 Relative abundance of Canada- and Ontario-based peer-reviewed papers. The search ('biomass' or 'coal' or 'co-fire') and ('employ*'or 'product*' or 'community*') and ('electric*) yielded 4,954 articles, of which 4,851 articles were from outside Canada [42]. The first narrowed down search which included the search term 'Canada' yielded 93 articles. The second narrowed down search which included the search term 'Ontario' yielded 10 articles.

conducted outside of Ontario, Canada, we had to rely primarily on these studies from other jurisdictions.

From the results of our second query, it was noted that the top five countries' institutional affiliations are (1) United States, (2) People's Republic of China, (3) England, (4) Germany and (5) Sweden. However, this list might be misleading since it reflects countries where universities and other research institutions are located but not necessarily where the research is taking place on the ground. This list also does not indicate where biomass utilization is currently being employed on a production scale although 'abundant resources and favourable policies' have allowed Northern Europe and the United States to expand biomass utilization for power [52]. Wherever possible, we have generalized and related these findings to the Ontario context, addressing the local socio-economic impacts relating to $100 \%$ biomass burning, $100 \%$ coal burning and co-firing biomass with coal.

We reviewed over 150 sources in depth, which included peer-reviewed articles and non-peer-reviewed grey literature such as government documents, nongovernmental organization (NGO) reports and news publications. Of those sources, 74 bearing relevance to our study were cited and summarized in Table 1. It became apparent that a gap exists in the peer-reviewed literature related to Canadian studies investigating woody biomass burning for thermoelectric production. We found eight sources which discuss biomass burning in Canada (relevant to this study), of which only three are peer-reviewed journal articles. Out of the 74 sources cited in this paper, only 27 of these are peer-reviewed journal articles, with the other articles being classed as 
Table 1 Publications identified and reviewed based on fuel location and impacts

\begin{tabular}{|c|c|c|}
\hline & Number & Percent \\
\hline \multicolumn{3}{|l|}{ Literature type } \\
\hline Peer review & 27 & 36.49 \\
\hline Government publication & 16 & 21.62 \\
\hline Academic textbook & 6 & 8.11 \\
\hline Corporation publication & 5 & 6.76 \\
\hline NGO publication & 7 & 9.46 \\
\hline International Governmental Agency & 3 & 4.05 \\
\hline Trade publication & 3 & 4.05 \\
\hline Newspaper/magazine & 3 & 4.05 \\
\hline Other & 4 & 5.41 \\
\hline Total & 74 & 100.00 \\
\hline \multicolumn{3}{|l|}{ Location } \\
\hline Canada & 35 & 47.30 \\
\hline Generalized global & 15 & 20.27 \\
\hline Abroad & 9 & 12.16 \\
\hline US & 6 & 8.11 \\
\hline Multiple jurisdictions & 5 & 6.76 \\
\hline N/A & 4 & 5.41 \\
\hline Total & 74 & 100.00 \\
\hline \multicolumn{3}{|l|}{ Fuel } \\
\hline N/A & 22 & 29.73 \\
\hline Biomass & 18 & 24.32 \\
\hline Multiple fuels & 17 & 22.97 \\
\hline Coal & 10 & 13.51 \\
\hline Co-fire & 4 & 5.41 \\
\hline Other & 3 & 4.05 \\
\hline Total & 74 & 100.00 \\
\hline \multicolumn{3}{|l|}{ Combinations } \\
\hline Peer review and Canada & 9 & \\
\hline Canada and biomass & 8 & \\
\hline Peer review, Canada and biomass & 3 & \\
\hline
\end{tabular}

Over 150 articles were reviewed, and 74 are cited here and tagged to literature type, location, fuels and novel combinations.

academic text books or government, NGO, corporation and trade publications (Table 1). Although non-peer -reviewed literature is an excellent source for knowledge, it is not always subject to the same academic critical review as peer-reviewed journal articles are subjected to.

A primary factor in assessing local socio-economic impacts is the extent to which economic activities remain within the region. In Canada, thermoelectric stations are often built near the fuel source, commonly known as mine-mouth [53], examples include Boundary Dam Power Station and Poplar River Power Station in Saskatchewan and Sheerness Thermal Generating Station in Alberta. However, AGS has no nearby mine and uses lignite coal, which is shipped approximately $1,000 \mathrm{~km}$ on rail from Bienfait, Saskatchewan. Although lignite coal and wood pellets tend to have similar energy density (Table 2), woody biomass is still more expensive to produce and hence generally requires short transportation distances to be most cost-effective $[17,54]$ in the absence of subsidies or other incentives. The data in Table 2 are primarily quantitative in nature and generally a good indicator of differences in the three burning scenarios. However, a potential weakness of the values presented is related to varying market conditions. It is possible that these values for coal, biomass and co-firing may fluctuate, potentially rendering these values less helpful in reality and in the Ontario context.

The phase out from coal to biomass in Atikokan has the potential to provide new local benefits such as necessitating a local biomass supply chain [15], and it is speculated that it could not only secure current jobs but also create new ones [54]. It has been reported that a greater number of people can benefit from woody biomass production since direct labour inputs for woody biomass production can range anywhere from 2 to 3 times [65] up to 20 times [15] greater than coal.

The utilization of woody biomass in co-firing, as with $100 \%$ biomass, has the potential to develop localized wood pellet industries (albeit on a smaller scale) which can benefit local rural economies [70]. However, local benefit from woody biomass may not always be realized. If the quantity of required wood pellets is low relative to coal, it may be more feasible to transport biomass a greater distance rather than create a local production facility.

The World Business Council for Sustainable Development (WBCSD) recently published a report evaluating 10 assessment tools for evaluating a company's socioeconomic impact [71]. Their criteria for inclusion were twofold. Firstly, for a tool to be included, it had to focus solely on socio-economic impacts, and secondly, it had to be developed primarily for business. The document presents and defines the 10 tools, assessing them on 9 dimensions. The dimensions fall under two broad categories: (1) strategic fit (i.e. secure licence to operate, improve business enabling environment, strengthen value chains, fuel product and service innovation) and (2) applicable levels (i.e. site, value chain, business line, company operations at the national level and company). For each tool, the document also outlines the degree of guidance provided, data requirements, level of effort and example case studies.

In order to properly evaluate the impacts of AGS transition from coal to biomass, choosing the most appropriate method is imperative. Of the nine dimensions outlined in the WBCSD report, we identified 'maintaining license to 
Table 2 Comparison of local socio-economic impact factors of burning scenarios

\begin{tabular}{|c|c|c|c|c|c|c|c|}
\hline Fuel & $\begin{array}{l}\text { Gross calorific } \\
\text { value }(\mathrm{MJ} / \mathrm{kg})\end{array}$ & $\begin{array}{l}\text { Cost per weight } \\
(\$ / \mathrm{kg})\end{array}$ & $\begin{array}{l}\text { Cost per caloric } \\
\text { value }(\$ / \mathrm{MJ})\end{array}$ & $\begin{array}{l}\text { Transportation in } \\
\text { Canada }\end{array}$ & Transportation to Aikokan, ON & $\begin{array}{l}\text { Relative GHG emissions } \\
\text { and carbon neutrality } \\
\text { hypothesis (g CO2/kWh*h) }\end{array}$ & $\begin{array}{l}\text { Waste by-products and } \\
\text { disposal }\end{array}$ \\
\hline Coal & $\begin{array}{l}25 \text { to } 27[17,55,56] \\
7 \text { to } 18 \text { (lignite) [57] }\end{array}$ & $0.05[58]$ & $\begin{array}{l}\$ 0.0019 / \mathrm{MJ} \text { to } \\
\$ 0.0020 / \mathrm{MJ} \\
\text { (lignite) }\end{array}$ & $\begin{array}{l}\text { Mine mouth in many } \\
\text { instances } 1,000 \mathrm{~s} \text { of } \mathrm{km} \\
\text { primarily by rail, with } \\
\text { some road depending } \\
\text { on where production } \\
\text { facility is located }[53,59]\end{array}$ & $\begin{array}{l}\text { Lignite coal is currently shipped } \\
\text { approximately } 1,000 \mathrm{~km} \text { from } \\
\text { Benoit, SK. All fuel production is } \\
\text { located well outside Atikokan's } \\
\text { jurisdiction. }\end{array}$ & $\begin{array}{l}850 \text { to } 1116[22,60] \text { Coal releases } \\
\text { carbon which was sequestered } \\
225 \text { to } 345 \text { million years ago } \\
{[55,61] .}\end{array}$ & $\begin{array}{l}\text { Fly ash can be used in } \\
\text { environmental applications } \\
\text { where markets dictate } \\
{[49,50,62] \text {. }}\end{array}$ \\
\hline $\begin{array}{l}\text { Wood } \\
\text { Pellets }\end{array}$ & 17 to $22[15,17,55]$ & 0.21 to $0.30[63,64]$ & $\begin{array}{l}\$ 0.012 / \mathrm{MJ} \text { to } \\
\$ 0.014 / \mathrm{MJ}\end{array}$ & $\begin{array}{l}\text { Transported } 100 \mathrm{~s} \text { of } \mathrm{km} \\
\text { primarily by road with } \\
\text { some rail [54] }\end{array}$ & $\begin{array}{l}\text { Relatively high cost per unit energy } \\
(\$ / M J) \text { necessitates relatively short } \\
\text { transportation distance from wood } \\
\text { pellet production facility. }\end{array}$ & $\begin{array}{l}39 \text { to } 80[22] \text { May be carbon } \\
\text { neutral }[51,65,66] \text { Releasing } \\
\text { carbon which was sequestered } \\
\text { within the past } 200 \text { years }[67]\end{array}$ & $\begin{array}{l}\text { Can be used for agricultural } \\
\text { and forestry purposes }[68,69]\end{array}$ \\
\hline Co-fire & $\begin{array}{l}\text { Depending on fuel } \\
\text { mix, values will vary } \\
\text { between coal and } \\
\text { wood pellets. }\end{array}$ & $\begin{array}{l}\text { Depending on fuel } \\
\text { mix, values will vary } \\
\text { between coal and } \\
\text { wood pellets. }\end{array}$ & $\begin{array}{l}\text { Depending on fuel } \\
\text { mix, values will vary } \\
\text { between coal and } \\
\text { wood pellets. }\end{array}$ & $\begin{array}{l}\text { Depending on fuel mix, } \\
\text { values will vary between } \\
\text { coal and wood pellets. }\end{array}$ & $\begin{array}{l}\text { Depending on fuel mix, values will } \\
\text { vary between coal and wood } \\
\text { pellets. }\end{array}$ & 883 to $906[22]$ & $\begin{array}{l}\text { A potential concrete } \\
\text { additive [46] }\end{array}$ \\
\hline
\end{tabular}


operate' as a key dimension for evaluating potential methods for an impact assessment at AGS since this dimension is concerned with determining how business activities create 'net benefits for the economies and societies in which they operate [71]'. Furthermore, the 'site' level is most appropriate for the Atikokan context since we are most concerned with how the provincial coal cessation legislation affects the AGS site and nearby community. Selecting and employing a tool which address these two dimensions should effectively capture how changes at AGS affect the community.

Also, when evaluating a major change in a small town's primary industry, we feel that the selected tool must be readily available in order to expedite implementation and allow for future comparative analysis across other sites or contexts. A tool for the Atikokan context also needs to best lend itself to a developed country scenario. For example, one of the tools, 'Progress out of Poverty (PPI)' [71] would not likely be a viable option for Atikokan. Based on these criteria, possible candidate tools exist and may include the Global Environmental Management Initiative (GEMI) Metrics Navigator [72], measuring impact framework [73], or socio-economic assessment toolbox (SEAT) [74]. Regardless of the tool, each needs to be evaluated on its own merit and 'on functionality, fit for purpose, and cost and complexity of implementation [71]'.

\section{Conclusions}

In this review paper, we explored the literature related to burning coal and woody biomass for thermoelectric production with specific reference to socio-economic impacts. It was identified that changes in Ontario's energy policy which include the total ban on coal burning will have wide-reaching effects on how electricity will be produced in the province. Since there is very little peerreviewed research that directly relates to the province of Ontario (and Canada) and the transitions set to take place at AGS, we see this as a timely research opportunity.

We propose that the use of a carefully selected socioeconomic impact tool could effectively characterize potential socio-economic impacts as a community anticipates transitions related to a wholesale change in fuel utilization in its local thermoelectric generating station. In order for socio-economic impact assessment tools to be valid and meaningful, appropriate and robust local data must be collected through various means, following an accepted and proven approach, such as one or more of the tools presented by WBCSD [71] that will require local community involvement and support. This proposed research is necessary in order to address concerns raised by groups such as Greenpeace and to gain insight into the impacts of the transition from coal to woody biomass. Future research should explore these issues at a greater depth, using AGS as the only North American case study of this scale currently available.

\section{Endnotes}

${ }^{a}$ It should be noted that nuclear power proponents often promote this energy source as 'green'.

${ }^{\mathrm{b}}$ All OPG thermoelectric plants produce solely electricity, with no facilities currently producing heat under a combined heat and power (CHP) system, although the Ontario Power Authority is interested in developing CHP in Ontario. c.f. http://www.powerauthority.on.ca/ update-chpcesop.

${ }^{\mathrm{c}}$ The Thomson Reuters (ISI) Web of Knowledge is described as a premier literature and abstract database platform, which has been designed to help researchers to 'quickly find, analyze, and share information in the sciences, social sciences, arts, and humanities'.

${ }^{\mathrm{d}}$ Google Scholar is a Google search engine optimized for searching scholarly literature across disciplines and sources such as articles, theses, books, professional societies and online repositories.

\section{Abbreviations}

AGS: Atikokan Generating Station; $\mathrm{CO}_{2}$ : Carbon dioxide; ENGO: Environmental non-governmental organization; GEMl: Global Environmental Management Initiative; GHG: Greenhouse gases; kWh: Kilowatt hour; MJ: Mega joule; MOE: Ontario Ministry of the Environment; OPG: Ontario Power Generation; PPI: Progress out of Poverty Indicator; SEAT: Socio-economic assessment toolbox.

\section{Competing interests}

The authors declare that they have no competing interests.

\section{Authors' contributions}

All authors contributed to this review. JEED and CS collected and sorted the sources and information material and prepared the manuscript. HL provided critical revisions and provided technical input related to literature analysis and socio-economic impacts. NL provided critical revisions and technical input related to forest management practices in Ontario. All authors read and approved the final manuscript.

\section{Acknowledgements}

The corresponding author, a PhD candidate, was funded by the Natural Resources and Engineering Research Council of Canada through an Industrial Postgraduate Scholarship in partnership with Ontario Power Generation. The authors are very grateful for the ongoing support to this project provided by Daryl Gaudry, Brent Boyko, Jane Todd and the entire staff at OPG Thunder Bay and Atikokan Generating Stations. Additional funding was provided by the Centre for Research and Innovation in the Bio-Economy (CRIBE). The authors also wish to thank the two anonymous reviewers whose critiques have greatly improved the manuscript.

\section{Author details}

${ }^{1}$ Lakehead University, Faculty of Natural Resources Management, 955 Oliver Road, Thunder Bay, Ontario P7B 5E1, Canada. 'Lakehead University, School of Outdoor Recreation Parks and Tourism, 955 Oliver Road, Thunder Bay,

Ontario P7B 5E1, Canada.

Received: 25 October 2012 Accepted: 8 May 2013

Published: 30 May 2013

\section{References}

1. Ontario Ministry of the Environment (2010) Green Energy Act., http://www. ene.gov.on.ca/environment/en/legislation/green_energy_act/index.htm. Accessed 28 Jan 2013 
2. Ontario (2009) Green Energy Act, 2009 S.0. 2009, CHAPTER 12 Schedule A. Ontario e-Laws, 2009th Edn., http://www.e-laws.gov.on.ca/Download/ elaws_statutes_09g12_e.doc. Accessed 28 Jan 2013

3. Holmes M (2012) All over the map 2012: a comparison of provincial climate change plans. David Suzuki Foundation, Vancouver

4. International Energy Agency (IEA) (2009) World energy outlook 2009 Organisation for Economic Co-operation and. Development/International Energy Agency, Paris

5. Ontario (2007) Cessation of coal use. Ontario Regulation 496/07., http:// www.e-laws.gov.on.ca/html/regs/english/elaws_regs_070496_e.htm. Accessed 4 April 2013

6. Ministry of Energy and Infrastructure (MEI) (2009) Ontario's coal phase out plan., http://news.ontario.ca/mei/en/2009/09/ontarios-coal-phase-out-plan. html. Accessed 4 Apr 2013

7. Marshall L, Fralick C, Gaudry D (2010) OPG charts move from coal to biomass power., http://www.powermag.com/coal/OPG-Charts-Move-fromCoal-to-Biomass_2570.html. Accessed 17 Feb 2013

8. Human Resources and Skills Development Canada (HRSDC) (2013) Definition — Well-being., http://www4.hrsdc.gc.ca/gl.4ss.1ry@-eng.jsp? wrd=Well-being. Accessed 2 April 2013

9. Ontario Power Generation (OPG) (2011) Atikokan Generating Station biomass repowering project fact sheet. Ontario Power Generation, Toronto

10. OPG Ontario Power Generation (2011) Atikokan Generating Station brochure. Ontario Power Generation, Inc, Toronto

11. McKinnon M (2011) OPG details the move to biomass., http://www. atikokanprogress.ca/2011/03/23/opg-details-the-move-to-biomass/. Accessed 8 Dec 2011

12. Ontario Power Generation (OPG) (2012) Atikokan Generating Station biomass fuel suppliers announced: meeting the needs of a growing economy in Northwestern Ontario., http://www.opg.com/news/releases/ 121122Atikokan\%20Fuel\%20Contracts_FINAL.pdf. Accessed 28 Jan 2013

13. Alam MB, Pulkki R, Shahi C (2012) Woody biomass availability for bioenergy production using forest depletion spatial data in northwestern Ontario. Can J For Res 42:506-516

14. Morais J, Barbosa R, Lapa N, Mendes B, Gulyurtlu I (2011) Environmental and socio-economic assessment of co-combustion of coal, biomass and nonhazardous wastes in a Power Plant. Resour Conserv Recycl 55:1109-1118

15. Van Loo S, Koppejan J (eds) (2010) The handbook of biomass combustion \& co-firing. Earthscan, London

16. Zhang Y, McKechnie J, Cormier D, Lyng R, Mabee W, Ogino A, MacLean HL (2010) Life cycle emissions and cost of producing electricity from coal, natural gas, and wood pellets in Ontario, Canada. Environ Sci Technol 44:538-544

17. Pansini AJ, Smalling KD (2006) Guide to electric power generation. The Fairmont Press, Lilburn

18. Brockschink SR, Gurney JH, Seely DB (2006) Hydroelectric power generation. In: Grigsby LL (ed) Electric power generation, transmission, and distribution. CRC Press, Boca Raton

19. Sher J (2011) Ontario launches wind, solar projects., http://www.torontosun. com/2011/07/05/ontario-launches-wind-solar-projects. Accessed 4 Apr 2013

20. Nishimura K (2012) Grassroots action for renewable energy: how did Ontario succeed in the implementation of a feed-in tariff system? Energy, Sustainability and Society 6., http://www.energsustainsoc.com/content/2/1/6

21. Independent Electricity System Operator (IESO) (2011) New Releases., http:// www.ieso.ca/imoweb/media/md_news.asp Accessed 2 Dec 2011

22. Cuddihy J, Kennedy C, Byer P (2005) Energy use in Canada: environmental impacts and opportunities in relationship to infrastructure systems. Can $J$ Civ Eng 32:1-15

23. Bhattacharyya SC (1997) An estimation of environmental costs of coal-based thermal power generation in India. Int J Energ Res 21:289-298

24. Aitken M (2007) Public opinion on electricity options: Postnote 294 Parliamentary Office of Science and. Technology, London

25. Brechin SR (2003) Comparative public opinion and knowledge on global climatic change and the Kyoto Protocol: the U.S. versus the world? Int J Sociol Soc Policy 23:106-134

26. Farhar BC, Houston AH (1996) Willingness to pay for electricity from renewable energy., NREL/TP-460-21216. Golden, Colorado

27. Farhar BC (1994) Trends in US public perceptions and preferences on energy and environmental policy. Annu Rev Energy Env 19:211-239

28. Bang H, Ellinger AE, Hadjimarcou J, Traichal PA (2000) Consumer concern, knowledge, belief, and attitude toward renewable energy: an application of the reasoned action theory. Psychol Mark 17:449-468
29. Baxter $L$ (2005) Biomass-coal co-combustion: opportunity for affordable renewable energy. Fuel 84:1295-1305

30. van der Horst D (2007) NIMBY or not? Exploring the relevance of location and the politics of voiced opinions in renewable energy siting controversies. Energy Policy 35:2705-2714

31. Upreti BR, van der Horst D (2004) National renewable energy policy and local opposition in the UK: the failed development of a biomass electricity plant. Biomass Bioenergy 26:61-69

32. Mainville N (2011) Fueling a biomess: why burning trees for energy will harm people, the climate and forests. Greenpeace, Montreal

33. Ontario (1994) Crown Forest Sustainability Act., http://www.e-laws.gov.on.ca/ html/statutes/english/elaws_statutes_94c25_e.htm. Accessed 23 Aug 2012

34. Ontario Ministry of Natural Resources (OMNR) (2012) Forest Management Guides., http://www.mnr.gov.on.ca/en/Business/Forests/2ColumnSubPage/ STEL02_164533.html. Accessed 11 Feb 2013

35. Ontario Ministry of Natural Resources (OMNR) (2007) Forest management guide for cultural heritage values. Queen's Printer for Ontario, Toronto

36. Ontario Ministry of Natural Resources (OMNR) (2001) Management guidelines for forestry and resource-based tourism. Queen's Printer for Ontario, Toronto

37. Ontario Ministry of Natural Resources (OMNR) (2010) Forest management guide for conserving biodiversity at the stand and site scales. Queen's Printer for Ontario, Toronto

38. Ontario Ministry of Natural Resources (OMNR) (2001) Forest management guide for natural disturbance pattern emulation. Queen's Printer for Ontario, Toronto

39. Watt WR, Baker JA, Hogg DM, McNicol JG, Naylor BJ (1996) Forest management guidelines for the provision of marten habitat. Queen's Printer for Ontario, Toronto

40. Racey G, Harris A, Gerrish L, Armstrong T, McNicol J, Baker J (1999) Forest management guidelines for the conservation of woodland caribou: a landscape approach. Ontario Ministry of Natural Resources, Thunder Bay

41. Ontario Ministry of Natural Resources (OMNR) (2003) Declaration Order regarding MNR's Class Environmental Assessment (EA) Approval for Forest Management on Crown Lands in Ontario (MNR-71). Queen's Printer for Ontario, Toronto

42. Thompson Reuters (2012) Web of Science., http://www.webofknowledge. com. Accessed 25 Jan 2013

43. Sikkema R, Steiner M, Junginger M, Hiegl W, Hansen MT, Faaij A (2011) The European wood pellet markets: current status and prospects for 2020. Biofuels, Bioprod Biorefin 5:250-278

44. Hansson J, Berndes G, Johnsson F, Kjarstad J (2009) Co-firing biomass with coal for electricity generation - an assessment of the potential in EU27. Energy Policy 37:1444-1455

45. Google (2012) Google Scholar., http://scholar.google.ca/. Accessed 2 Apr 2012

46. Johnson A, Catalan LJ, Kinrade SD (2010) Characterization and evaluation of fly-ash from co-combustion of lignite and wood pellets for use as cement admixture. Fuel 89:3042-3050

47. Hosegood S, Leitch M, Shahi C, Pulkki R (2011) Moisture and energy content of fire-burnt trees for bioenergy production: a case study of four tree species from northwestern Ontario. For Chron 87:42-47

48. Alam MB, Pulkki R, Shahi C, Upadhyay T (2009) Wood biomass procurement for bioenergy production in northwestern Ontario: a decision support system based on mixed integer programming model., In: 34th Council on Forest Engineering, Quebec City, 12-15 June 2011

49. Wang H, Shang J, Xu Y, Yeheyis M, Yanful E (2007) Application of coal fly ash to replace lime in the management of reactive mine tailings. Appropriate Technologies for Environmental Protection in the Developing World., Paper presented at the ERTEP 2007, Ghana, 17-19 July 2007

50. Yeheyis MB, Shang JQ, Yanful EK (2008) Characterization and environmental evaluation of Atikokan coal fly ash for environmental applications. J Environ Eng Sci 7:481-498

51. Ter-Mikaelian MT, McKechnie J, Colombo SJ, Chen JX, MacLean HL (2011) The carbon neutrality assumption for forest bioenergy: a case study for northwestern Ontario. For Chron 87:644-652

52. International Energy Agency (IEA) (2007) Biomass for Power Generation and CHP. IEA Energy Technology Essentials ETE03. International Energy Agency, Paris

53. Centre for Energy (CFE) (2012) Transporting coal., http://www. centreforenergy.com/AboutEnergy/Coal/Environment.asp?page=14. Accessed 2 April 2012 
54. Kryzanowski T (2010) Pellet production boom. Logging Sawmill J, http:// www.forestnet.com/LSJissues/march_10/pellet\%20boom.pdf. Accessed 2 April 2012

55. McKendry P (2002) Energy production from biomass (part 1): Overview of biomass. Bioresour Technol 83:37-46

56. Demirbas A (2003) Biomass co-firing for coal-fired boilers. Energ Explor Exploit 21:269-278

57. Schobert HH (1995) Lignites of North America. Elsevier Science, Amsterdam

58. Coleman L (2011) 2010 Coal producers survey. National Mining Association, Washington

59. Smith EB (2005) A mountain of coal waits for a ride., http://www.usatoday. com/money/industries/manufacturing/2005-08-24-coal-usat_x.htm. Accessed 2 Apr 2012

60. International Energy Agency (IEA) (2011) Power generation from coal. International Energy Agency, Paris

61. Anderson DA (2010) Environmental economics and natural resource management. Routledge, New York

62. Wang HL, Shang JQ, Kovac V, Ho KS (2006) Utilization of Atikokan coal fly ash in acid rock drainage control form Musselwhite Mine tailings. Can Geotech J 43:229-243

63. Obernberger I, Thek $G$ (2010) The pellet handbook: the production and thermal utilisation of biomass pellets. Earthscan, Washington

64. Pirraglia A, Gonzales R, Saloni D, Wright J (2010) Wood pellets: an expanding market opportunity. Biomass Power \& Thermal, http:// biomassmagazine.com/articles/3853/wood-pellets-an-expanding-marketopportunity/. Accessed 15 Sept 2012

65. Abbasi T, Abbasi SA (2010) Biomass energy and the environmental impacts associated with its production and utilization. Renew Sustain Energy Rev 14:919-937

66. Akella AK, Saini RP, Sharma MP (2009) Social, economical and environmental impacts of renewable energy systems. Renew Energy 34:390-396

67. Marland G, Schlamandinger B (1997) Forests for carbon sequestration or fossil fuel substitution: a sensitivity analysis. Biomass Bioenergy 13:389-397

68. Nardoslawsky M, Obernberger I (1996) From waste to raw material: the route from biomass to wood ash for cadmium and other heavy metals. Hazard Mater 50:157-168

69. Demeyer A, Voundi Nkana JC, Verloo MG (2001) Characteristics of wood ash and influence on soil properties and nutrient uptake: an overview. Bioresour Technol 77:287-295

70. Al-Mansour F, Zuwala J (2010) An evaluation of biomass co-firing in Europe. Biomass Bioenergy 34:620-629

71. World Business Council for Sustainable Development (WBCSD) (2013) Measuring socio-economic impact: a guide for business. World Business Council for Sustainable. Development, Washington

72. Global Environmental Management Initiative (GEMI) (2007) The Metrics Navigator. Global Environmental Management Initiative, Washington

73. Initiative for Global Development (IGD) Measuring impact: a business approach. Initiative for Global Development, Seattle

74. Anglo American (2012) Socio-economic assessment toolbox. Version 3. Anglo American Services UK Ltd, London

doi:10.1186/2192-0567-3-11

Cite this article as: Dampier et al:: From coal to wood thermoelectric energy production: a review and discussion of potential socio-economic impacts with implications for Northwestern Ontario, Canada. Energy, Sustainability and Society 2013 3:11.

\section{Submit your manuscript to a SpringerOpen ${ }^{\circ}$ journal and benefit from:}

- Convenient online submission

- Rigorous peer review

- Immediate publication on acceptance

- Open access: articles freely available online

- High visibility within the field

- Retaining the copyright to your article

Submit your next manuscript at $\gg$ springeropen.com 